\title{
Application of Lubrication into the Hip Joint Replacement
}

Andrea Haringová, Karol Stračár, Karol Prikkel

Faculty of Mechanical Engineering STU in Bratislava, Námestie Slobody 17, 81231 Bratislava 1, Slovak Republic, Email: andrea.haringova@stuba.sk, karol.stracar@stuba.sk, karol.prikkel@stuba.sk

The article deals with application of knowledge from lubrication of healthy spherical joints into hip joint endoprosthesis. As the observed most important physical parameter it was selected the coefficient of friction responsible directly for lifetime of the endoprosthesis. The article describes as well as experimentally verifies the idea of additional lubrication of hip joint endoprosthesis.

Keywords: lubrication, coefficient of friction, endoprosthesis.

\section{Acknowledgements}

The research presented in this paper is an outcome of the project No. APVV-0857-12 "Tools durability research of progressive compacting machine design and development of adaptive control for compaction process" funded by the Slovak Research and Development Agency.

\section{References}

[1] MEDLEY, J. B. (1981). The lubrication of normal human ankle joints, pp. 443, Department of Mechanical Engineering, The University of Leeds, England.

[2] WIERZCHOLSKI, K. (2010). Friction force and pressure calculation for time dependent impulsive intelligent lubrication of human hip joint, In Acta of bioengineering and biomechanics, Vol. 12, No. 3.

[3] HARINGOVÁ, A. - PRIKKEL, K. (2013). The designing of stand for testing of hip joint endoprosthesis, In: ERIN Journal of Slovak University of Technology, ISSN 1337-9089.

[4] HARINGOVÁ, A. - PRIKKEL, K. (2012). Effective thickness of synovial fluid layer in the gap of endoprosthesis of hip joint, pp. 4, In: Hydraulika a pneumatika, ISSN 1335-5171, vol. 12, No. 1-2.

[5] PRIKKEL, K - HARINGOVÁ, A. (2013). Endoprotéza kíbu, najmä bedrového kíbu, Číslo úžitkového vzoru: 6377 SK, 6376 SK, Vestník ÚPV SR, Vol. 13, No. 2.

[6] HART, R. - ROZKYDAL, Z. (1999). Dlouhodobé výsledky totální endoprotézy kycelního kloubu Poldi, pp. 139 - 145, In: Acta Chirurgiae orthopaedicae et Traumatologicae Cechoslovaca, No. 66.

[7] GALLO, J., HAVRÁNEK, V., ZAPLETALOVÁ, J., MANDÁT, D. (2006). Merení oteru polyetylenových jamek TEP kycelního kloubu univerzálním mericím mikroskopem, pp. 28 - 33, In Acta Chirurgiae orthopaedicae et Traumatologicae Cechoslovaca, No. 73.

[8] SEEBECK, P. (2009). Clinical and Technical Review: Hyaluronic acid (Hyaluronan), pp.24, TECOmedical Group.

[9] YUAN, L. (2004). Numerical study of multiple periodic flow states in spherical Couette flow, pp.81-91, ICMES \&LSEC, Chinese Academy of Sciences, ISSN 1006- 9283.

[10] ISO 14242-1:2012. Implants for surgery.

[11] ISO 7206-1:2008. Implants for surgery- Partial and total hip jointprostheses.

[12] PELAGIĆ, Z., NÁGEL', M., ŽMINDÁK, M., RIECKY, D. (2015). Wear Simulation Modeling by Using the Finite Element Method, pp.191-195, In: Manufacturing technology, Vol. 15, No. 2.

[13] SEDLAK, J, SLANY, M, FIALA, Z, JAROS, A, BLAZKOVA, V. (2015). Testing of Implant Prototype of Femoral Component Using Hydraulic Machine ZD40, pp.416-423, In: Manufacturing technology, Vol. 15, No. 3.

[14] CIESLAR, J., BROŽEK, M., BEDNÁř, B. (2013). An Experimental Assessment of Special Metal Castings in Reducing Abrasive Wear, pp.423-428, In: Manufacturing technology, Vol. 13, No. 4.

[15] GALANIS, N.I., MARKOPOULOS, A.P., GIANNAKOPOULOS, I.D., MANOLAKOS, D.E. (2013). Manufacturing of Femoral Heads from Ti-6Al-4V Alloy with High Speed Machining: 3D Finite Element Modelling and Experimental Validation, pp.437-444, In: Manufacturing technology, Vol. 13, No. 4.

[16] BAKALOVA, .T, LOUDA, P., VOLESKÝ, L., ANDRŠOVÁ, Z. (2014) The Use of Optical Microscopy to Evaluate the Tribological Properties, pp. 256-261, In: Manufacturing technology, Vol. 14, No. 3. 